- RESEARCH ARTICLE -

\title{
IS KUZNETS' INVERTED-U HYPOTHESIS VALID FOR TURKEY?: ARDL BOUNDS TESTING APPROACH
}

\author{
Cüneyt KILIÇ ${ }^{1} \&$ Ünzüle KURT ${ }^{2} \&$ Gülistan $C A N^{3}$
}

\begin{abstract}
Kuznets (1955) stated that in the early stages of a society's economic development, income inequality would increase with economic growth, and in the later stages of economic growth, income inequality would decrease. The aim of this study is to analyze whether Kuznets (1955) hypothesis was valid for the Turkish economy with the help of ARDL boundary test approach using data from 1987-2019 period. As a result of the analysis, it was found that there is a negative relationship between economic growth and income inequality. These results indicate that Kuznets' inverted-U hypothesis is not valid in Turkey, but rather that the relationship between economic growth and income inequality is similar to the U-shape.
\end{abstract}

Keywords: Income Inequality, Economic Growth, Kuznets Curve, ARDL Boundary Test.

JEL Codes: $O 15, O 47, C 22$.

Başvuru: 13.03.2021

Kabul: 23.04 .2021

\section{TÜRKIYYE'DE KUZNETS'İN TERS-U HİPOTEZİ GEÇERLİ Mİ?: ARDL SINIR TESTI YAKLAŞIMI ${ }^{4}$}

$\ddot{O} z$

Kuznets (1955) bir toplumun ekonomik gelişiminin ilk aşamalarında ekonomik büyüme ile birlikte gelireşitsizliğinin artacă̆ını, ekonomik gelişmesinin ilerleyen aşamalarında ise ekonomik büyüme ile gelir eşitsizliğinin azalacağını ifade etmektedir. Bu çalışmanın amacı Kuznets (1955)'in ortaya atmış olduğu bu hipotezin Türkiye ekonomisinde geçerli olup/olmadiğını 1987-2019 dönemine ait verileri kullanarak ARDL sinır testi yaklaşımı yardımıyla analiz etmektir. Analiz sonucunda ekonomik büyüme ile gelir eşitsizliği arasında negative yönlü bir iliş̧ki olduğu tespit edilmiştir. Bu sonuçlar Türkiye'de Kuznets'in ters-U hipotezinin geçerli olmadığını bunun aksine ekonomik büyüme ile gelir eşitsizliği arasındaki iliş̧kinin U şekline benzediğini göstermektedir.

Anahtar Kelimeler: Gelir Eşitsizliği, Ekonomik Büyüme, Kuznets Ĕgrisi, ARDL Sınır Testi.

\footnotetext{
1Professor, Canakkale Onsekiz Mart University, Biga Faculty of Economics and Administrative Sciences, Department of Economics, Çanakkale TÜRKIYE, C_kilic2006@ hotmail.com, ORCID: 0000-0003-0622- 7145. ${ }^{2}$ A ssociate Professor, Canakkale Onsekiz M art University, Biga Faculty of A pplied Sciences, Department of B anking and Finance, Çanakkale TÜRKIYE, unzulekurt17@ gmail.com, ORCID: 0000-0003-3406-1269.

${ }^{3}$ Research A ssistant, Canakkale Onsekiz M art U niversity, Biga Faculty of Economics and A dministrative Sciences, Department of Economics, Çanakkale TÜRKIYE, glstncn.17@ gmail.com, ORCID: 0000-0001-90268729.

${ }^{4}$ Genişletilmiş Türkçe Özet, makalenin sonunda yer almaktadır.
} 
JEL Kodları: $O 15, O 47, C 22$.

Bu çalışma Araştırma ve Yayın Etiğine uygun olarak hazırlanmıştır.

\section{INTRODUCTION}

Economic growth and income distribution are among the most discussed topics by researchers in recent years. Economic growth is expressed as the numerical real increase in the production capacity of the economy or real gross domestic product in a certain period in an economy (Ivic, 2015: 55-56). Income distribution is the name given to the distribution of income generated in a certain period in an economy among individuals or production factors (labor, capital, natural resources, and entrepreneurs) (Cow ell, 2007: 2-3).

A mong the most important goals of economic policies are to ensure stable and sustainable economic growth and a fair distribution of income. Different economic policies are applied around the world in order to achieve these goals. Although the implemented policies led to progress in economic growth in certain periods, it is seen that they are insufficient in income inequality, and even in recent years (late 1990s and early 2000s), income inequality has increased in high, middle, and low-income countries (UNDP, 2013: 63-67).

It is seen that some of the developments similar to those in the world are happening in Turkey. It is possible to examine the developments in economic growth and the Gini coefficient, which shows income inequality, in Turkey with the help of Graph 1.

Graph 1. The Development Process of Economic Growth and Gini Coefficient in Turkey

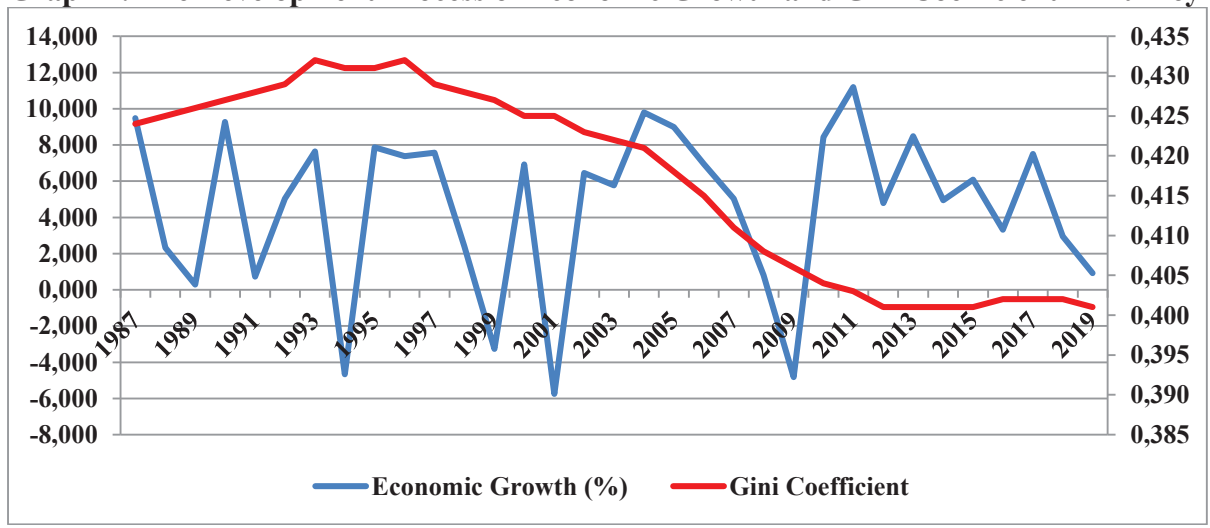

Note: Since the Gini coefficient data generated by Solt (2016) is not on a hundred (\%) scale, the data has been converted to a hundred system.

Source: (Compiled from the Standardized World Income Inequality Database (SW IIDVersion 9.0) created by the Solt (2016) and W orld Bank).

When Graph 1 is examined, it is seen that high growth rates have been reached in Turkey except during periods of economic crisis, but the economy has shrunk in years when 
economic crises have occurred (Such as 1989, 1994, 1999, 2000, 2001 and 2008) and their effects continue. While the Gini coefficient, which shows income inequality, had an increasing trend until 1996, it was observed to be in a decreasing trend from 1996 to 2012.

Although high growth rates have been achieved in many countries of the world in recent years, the positive course of economic growth does not reflect income inequality at the same level, and therefore increased income inequality has attracted the attention of researchers. From this point on arise the questions: Is there a relationship between economic growth and income inequality? What kind of relationship is there, if any? Kuznets (1955) began to investigate the answers to these questions. As a result of his research, he revealed that the relationship between economic growth and income inequality has an "inverted- $U$ " shape and he called it the "inverted-U hypothesis". Although this hypothesis, put forward by Kuznets (1955), was debated a lot at first, empirical studies in recent years show that the relationship between income inequality and economic growth occurs differently in each country or group of countries.

The aim of this study is to analyze whether the inverted- $U$ hypothesis put forward by K uznets (1955) is valid in the Turkish economy in the period 1987-2019. In the second section of the study, the theoretical framework of Kuznets (1955)'s inverted-U hypothesis is given, in the third section, empirical literature questioning the relationship between income distribution and economic growth in the context of Kuznets (1955) 's inverted-U hypothesis is reviewed, in the fourth section, the data, model, method and analysis findings are included, and in the fifth section, the study is concluded with the summary of the obtained results, evaluation and recommendations.

\subsection{Theoretical Framework of The Inverted-U Hypothesis}

The inverted-U hypothesis was first put forward by Simon K uznets in 1955. A ccording to this hypothesis, Kuznets (1955) stated that in the early stages of a society's economic development, income inequality will increase with economic growth, and after reaching its peak, income inequality will decrease with economic growth in the later stages of economic development (K uznets, 1955).

The inverted- $U$ hypothesis, which shows the relationship between income inequality and economic growth put forward by Kuznets (1955), is expressed by Kuznets' inverted-U curve in Figure 1. 


\section{Figure 1. Kuznets' Inverted-U Curve}

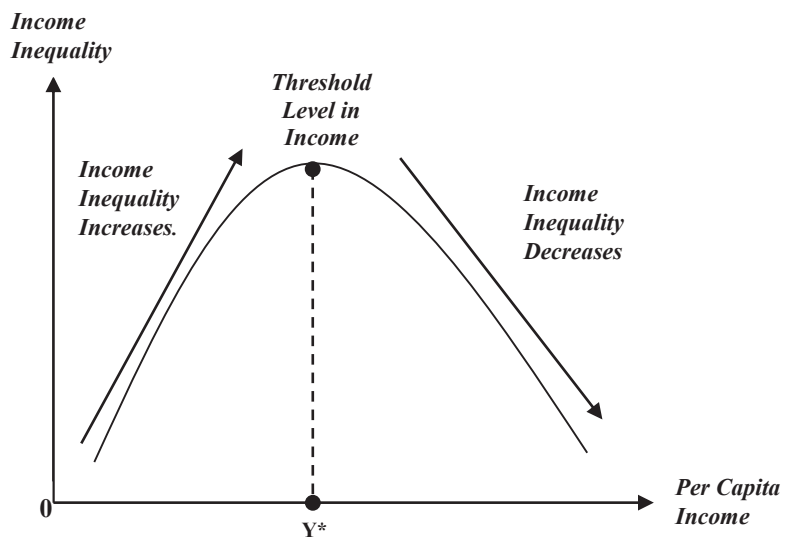

Source: (W eil, 2016: 389).

Kuznets' analysis showed that there is an inverted- $U$ shaped relationship between economic growth and income inequality in the world, as seen in Figure 1. The main reason for the emergence of this relationship is that in the early stages of economic development, people living in rural areas and engaged in agricultural activities started to migrate to the industrial sector where the expected wage is high and with this transition, income inequality increased significantly, but in the later stages of economic development, most workers migrate to places where the industrial sector is located, and a small number of workers remain in agriculture, so income inequality decreased (L yubimov, 2017: 44).

Two driving forces are required for the formation of Kuznets' inverted-U curve. First, it was observed that people with high-income levels in society save more, while people with lower incomes have lower rates of saving. People with high-income levels will get wealthier due to the cumulative effect of inequality in savings. W ith the increase in per capita income, it will be inevitable that income inequality will increase. The second is the changes caused by the shift of workers from low-income jobs to high-income jobs, that is, from the agricultural sector to the industrial sector (Kuznets, 1955: 10-11). In other words, it is possible to associate the differences in total inequality with changes in various sources of income. Such an alternative approach reveals the relationship among personal income distributions more clearly (D eutsch \& Silber, 2004: 110).

In his other work in 1963, Kuznets reached conclusions that supported his first work. He listed his results in 5 items as follows (K uznets, 1963: 67-68):

a) Income inequality in underdeveloped and developed countries is more common in the agricultural sector than in other sectors. At this point, the share of high-income groups is quite large.

b) Income inequality is higher in underdeveloped countries compared to developed countries. This difference is more pronounced in income after tax compared to income before taxation. 
c) Based on items $a$ and $b$, it is revealed that the income distribution in sectors other than the industrial sector is far from equality in underdeveloped countries compared to developed countries.

d) In the long-term, income inequality in developed countries is decreasing.

e) In the late 19th century and early 20th century, per capita income in least developed countries was much lower than in today's (1963) developed countries. This situation is likely to have enormous effects on welfare in the least developed countries.

K uznets guessed that this model was caused by dual economy dynamics that were created by the transition from the agricultural to the industrial sector. Lindert (1986) claimed in own study that the inverted- $U$ curve is caused by the decreasing importance of income from agricultural products. Williamson (1985), on the other hand, argued that technological advancement increased wages more than the rate of return on capital. Aghion and Bolton (1997) developed a model that allows people with low-income levels to invest as well by lowering interest rate (A cemoglu \& Robinson, 2002: 183-184).

This hypothesis, presented by Kuznets (1955), has been the subject of debate from the first day it was put forward to the present day. M any studies have been carried out to eliminate these discussions and to create a theoretical background to the subject. Historical studies in Western Europe confirm Kuznets (1955)'s hypothesis. For example, in England, the Gini coefficient increased from 0.400 in 1823 to 0.627 in 1871, but it decreased to 0.443 in 1900 (W illiamson, 1985, as cited in A cemoglu \& Robinson, 2002: 183). It has been observed that the situation in England supports Kuznets' hypothesis. Studies in many countries indicate contrary to the hypothesis has occurred.

\subsection{Literature Review}

When the literature on the relationship between income inequality and economic growth is examined in the context of K uznets (1955) inverted- $U$ hypothesis, it is seen that the literature does not date back to old times. Although the hypothesis was put forward in 1955, it began to be questioned and analyzed empirically much later. The main reason for this is the problems in obtaining data that measures income inequality. Although there are many institutions and organizations measuring income inequality, the questioning of the hypothesis was postponed due to the lack of stability in the continuity of the data.

$M$ any international studies are examining the relationship between income inequality and economic growth within the framework of Kuznets' inverted-U hypothesis (Ram, 1989; List and Gallet, 1999; Bahmani-Oskooee and Gelan, 2008; Shahbaz, 2010; Topuz and Dagdemir, 2016; A kyol, 2020). Including many countries in the analysis in Ram (1989), List and Gallet (1999), Topuz and Dagdemir (2016) and A kyol (2020) of these studies made it possible to reveal more clearly the international differences of the relationship between income inequality and economic growth.

Ram (1989) tested the relationship between income inequality and economic growth using the panel data analysis with the help of the data from the 1960-1980 period in 115 countries. In the study, Ram used Theil index to control the differences between countries and reached 
consequences that support Kuznets' inverted-U hypothesis. List and Gallet (1999) analyzed the relationship between income distribution and economic growth over the 1961-1992 period in 71 countries with the help of the panel data analysis. Their studies revealed that there is a positive relationship between income inequality and economic growth. They also stated that the most important contribution to this relationship was caused by the shift in production from the industrial sector to the service sector. Bahmani-Oskooee and Gelan (2008) investigated whether Kuznets' inverted- $U$ hypothesis was valid in the long period with the help of time series analysis using data from the 1957-2000 period of the United States. In their studies, they reached results that support the existence of K uznets' inverted- $U$ hypothesis in the short and long-term. Shahbaz (2010) analyzed whether K uznets' inverted-U hypothesis was valid in Pakistan during 1971-2005 with the help of the ARDL bounds testing. The analysis findings support K uznets' inverted- $U$ hypothesis, but it was concluded that the relationship between variables for Pakistan is in the form of an inverted-S curve. The fact that Shahbaz (2010) supports K uznets' inverted- $U$ hypothesis, as well as the inverted-S curve between economic growth and income inequality, makes this study different from other studies in the literature. Topuz and Dagdemir (2016) analyzed whether Kuznets' inverted-U hypothesis was valid using the panel data analysis method over the 1995-2011 period for 94 countries. Their studies revealed a positive relationship between economic growth and income inequality in low middle, low and upper middle-income countries, and a negative relationship between income inequality and economic growth in high-income countries. They stated that the results of their study support Kuznets' inverted-U hypothesis. Dogan and Cafri (2016) investigated whether K uznets' inverted-U curve or the great $U$-turn curve is valid for the period 2000-2012 in OECD countries using the dynamic panel data analysis method: They stated that the findings in their study support the great U-turn curve. Cakmak and Tosun (2017) anal yzed the validity of K uznets' inverted-U hypothesis using panel data analysis method using data from 2002-2013 in 25 upper-middle and high-income countries. They concluded that Kuznets' inverted- $U$ hypothesis is not valid, on the contrary, the relationship between variables was similar to the U-shape. A kyol (2020) tested the relationship between tourism activities and income inequality, and economic growth with the help of the panel data analysis using data from the 2003-2018 period in 72 developed and developing countries. In his analysis, he concluded that there is a positive relationship between tourism revenues and income inequality, and economic growth. He stated that these results prove that the K uznets curve is valid. The inclusion of tourism in A kyol (2020)'s study made his study different from other studies in the literature. Gunel (2020) analyzed whether Kuznets' inverted-U hypothesis is valid for the period 2000-2017 in Turkic Republics (A zerbaijan, Kazakhstan, K yrgyzstan, Tajikistan and Uzbekistan) using the panel data analysis. In his analysis, he concluded that income inequality increased in the early stages of economic growth and that income inequality decreased in the later stages in the Turkic Republics. A ccording to these results, he stated that K uznets' inverted-U hypothesis is valid in the Turkic Republics.

Some studies have analyzed whether K uznets (1955)'s inverted- $U$ hypothesis was valid for the Turkish economy. Empirical studies that do not support the existence of K uznets' inverted-U hypothesis have been conducted by Tokatloglu and Atan (2007), A kalin et al. (2018) and Limanli (2020). 
Tokatlioglu and Atan (2007) analyzed whether Kuznets curve is valid in regions with different levels of development in Turkey with the help of the cross-section analysis due to limited data. According to the findings of the analysis, they concluded that the K uznets curve in Turkey is the form of an inverted-U. K uznets' inverted- $U$ hypothesis is a hypothesis that covers the short and long period. Therefore, the horizontal cross-section analysis used in Tokatlioglu and A tan (2007) may not produce very clear results in terms of scope. A kalin et al. (2018) analyzed the relationship between income distribution and economic growth in the context of Kuznets' inverted-U hypothesis in Turkey with the help of the ARDL bounds testing approach using data from the 1984-2011 period. According to the results of the analysis, it was revealed that there is an inverted- $U$ shaped relationship between per capita income and the Gini coefficient, and accordingly, the Kuznets' hypothesis is valid in Turkey. Limanli (2020) tested the relationship between income inequality and GDP per capita in Turkey using data from the period 1964-2015 with the ARDL bounds testing approach. According to the findings of the cointegration test based on the bounds testing approach, it was revealed that there is a long-term relationship between the variables, and Kuznets' hypothesis is also valid in Turkey.

Some studies do not support the validity of Kuznets' inverted-U hypothesis in Turkey. There are many studies that have analyzed Kuznets ' inverted- $U$ hypothesis using different periods and analyses (Disbudak and Suslu, 2009; M ercan and A zer, 2013; Kanberoglu and A rvas, 2014; A Itunoz, 2015; A k and A ltintas, 2016; Takim et al., 2020). W hile some of these studies (A $k$ and Altintas, 2016; Takim et al., 2020) have findings that the "U " relationship is valid instead of the "inverted- $U$ " relationship, some studies (Disbudak and Suslu, 2009; K anberoglu and A rvas, 2014; A Itunoz, 2015) have revealed that there is a negative relationship between economic growth and income inequality.

Disbudak and Suslu (2009) examined whether the Kuznets hypothesis was valid in Turkey during the period 1963-1998 using the time series analysis method. In their study, they concluded that Kuznets' inverted-U hypothesis is not valid in Turkey, but rather that the relationship between variables is similar to the U-shape. M ercan and A zer (2013) investigated the relationship between income distribution and economic growth over the 1995-2009 period using the panel data analysis method in Central A sian and Caucasian economies (A zerbaijan, Kazakhstan, K yrgyzstan, Tajikistan, Turkmenistan, and Uzbekistan) and Turkey. In their analysis, they concluded that there is a positive long-term relationship between variables. However, they stated that the relationship between the variables in Turkey and A zerbaijan is in the opposite direction of the relationship across the panel. Kanberoglu and A rvas (2014) tested the relationship between income and financial development inequality in Turkey with the help of the ARDL bounds testing using data from the 1980-2002 period. In their studies, they used the share of private sector loans in GDP to represent financial development and GDP per capita to represent economic growth. As a result of their studies, they concluded that the $1 \%$ increase in financial development and economic growth reduced income inequality by 0.041 and 0.064 , respectively. K anberoglu and A rvas (2014) have also added the financial development variable to their work, unlike other studies in the literature. In this way, more comprehensive results have been obtained. Altunoz (2015) tested the relationship between income inequality and economic growth in Turkey with the help of the ARDL bounds testing using data from the 1991-2014 period. In its analysis, it concluded that the $1 \%$ increase in 
GDP per capita reduced income inequality by $0.055 \%$. According to the results of the analysis, it was revealed that $K$ uznets' inverted- $U$ hypothesis was not valid during the analysis period in Turkey. Ak and A Itintas (2016) analyzed whether K uznets' inverted-U hypothesis is valid for the period 1986-2012 in Turkey using the ARDL bounds testing approach. In the findings of the analysis, it was revealed that income inequality decreased as per capita income increased in the first stages of the economic growth process, and income inequality increased in the later stages of the economic growth process in Turkey. A ccording to these results, they also stated that the "U" relationship is valid instead of the "inverted-U" relationship between income inequality and economic growth in Turkey. Takim et al. (2020) examined the relationship between income distribution and economic growth in Turkey over the 1980-2017 period with the ARDL bounds testing approach. In their research, it was revealed that there is a positive relationship in the long-term and a negative relationship in the short-term between the variables.

When the literature review is evaluated in general, it is seen that a stable result cannot be obtained between economic growth and income inequality. For this reason, the results of some studies support that Kuznets' inverted-U hypothesis is valid, while others support that the relationship between variables is $U$-shaped.

\section{RESEARCH METHODOLOGY}

\subsection{Data and Model}

In econometric analysis, it is attempted to test whether the "inverted-U hypothesis" put forward by Kuznets (1955) is valid in Turkey. For this purpose, the Gini coefficient (the coefficient takes values from 0 to 1; 0 expresses perfect equality and 1 expresses perfect inequality) was used as the dependent variable in the econometric analysis to represent income inequality. As an independent variable, GDP per capita growth (\%) is included in the model to represent economic growth.

The econometric analysis period covers the period 1987-2019, and annual data were used in the analysis. The data of the econometric analysis period have been reached from two different sources. The Gini Coefficient data was obtained from the Standardized World Income Distribution Inequality Database (SW IID-V ersion 9.0) created by Solt (2016). Since this data created by Solt (2016) is not on a hundredth (\%) scale and the Gini Coefficient is a coefficient representing the income distribution in hundredths, the data obtained from the SW IID was converted into a hundredth system and included in the analysis. GDP per capita growth (\%) was obtained from the W orld Bank's W orld Development Indicators database.

When the literature testing the validity of K uznets' inverted- $U$ hypothesis is examined, it is seen that the models established are generally quadratic (second-order) models since there is no linear (first-order) relationship between income inequality and the level of per capita income. For this reason, a quadratic model was established to analyze whether the "invertedU hypothesis" put forward by Kuznets (1955) is valid in Turkey. The quadratic model is; 
$\mathrm{GINI}_{\mathrm{t}}=\beta_{0}+\beta_{1} \mathrm{EG}_{\mathrm{t}}+\beta_{2} E G^{2}+\beta_{3} D U M M Y_{t}+\varepsilon_{t}$

A bbreviations of variables in the model and the variable they represent are as follows: GINI: Gini Coefficient, used as independent variables; $\beta$ o: constant term; EG: economic growth; $\mathrm{EG}^{2}$ : the frame of economic growth, DUMMY: dummy variable that represents the period of structural break; $\varepsilon_{t}$ : the error term.

\subsection{Econometric Method}

Cointegration analysis is a method created to determine the existence of relationship between variables in the long-term. The classical cointegration method developed by Engle Granger (1987) and J ohansen (1988) analyzes the relationship between variables containing the same level of unit root. The same level of the stationary state, which is an important constraint for cointegration tests, was tried to be eliminated by the study of Peseran et al. (2001). The ARDL model developed in this framework has managed to overcome this constraint by arguing that a long-term relationship can be demonstrated even if the variables are stationary at different levels. The ARDL model provides more reliable results with the advantages of being applied to stationary series at the I(0) and I(1) levels and including the error correction model. ARDL model, which enables short and long-term relationships to be revealed by means of error correction model, is a model with high level of the explanatory power of dynamics between variables (A kel \& Gazel, 2014: 30-31).

In order to determine whether the ARDL model can be installed, a unit root test must be performed first. In the study, the unit root states of the variables were investigated using K PSS (1992) and Ziwot A ndrews (1992) methods. K wiatkowski et al. (1992) proposed LM statistics despite the hypothesis that the series is not stationary. The K PSS unit root test starts from a linear regression model (Cil Y avuz, 2004: 242).

$y_{t}=r_{t}+\beta t+\varepsilon_{t} \quad t=1, \ldots, T$

$r_{t}$, which is the autonomous parameter in the model, is in random walking time.

$r_{t}=r_{t-1}+u_{t}$

It is assumed that ut, which is the error term in the random process, is equality with independent and co-distribution properties $\left(0, \mathrm{ru}^{2}\right)$. In this case, the stationarity of the series is tested with the null hypothesis $\mathrm{H}_{0}: r_{u}{ }^{2}=0$. If the variance $\left(r_{u}\right)$ of the error term is zero, it will require that the error term (ut) to be constant and therefore stationary in the rt process, which is considered as a random process (Celik \& Tas, 2007: 17). In the KPSS unit root test, the al ternative hypothesis refers to the unit root in the series, and the null hypothesis refers to the stationary of the series.

U nit root tests, which take structural breaks into account, can be grouped according to the internal-external determination of the break or the number of breaks. The Perron (1997) and 
Zivot-A ndrews (1992) tests are tests in which structural break is specified as one-endogenous. The Zivot-Andrews' one-endogenous break test is a sequential test that uses a different dummy variable for every possible break and the whole sample. The break date is chosen based on the point where the unit root of the Augmented Dickey-Fuller test based on the $t$ statistic is minimum. In the Zivot-Andrews' unit root test with the structural break, three models were designed that allowed Model A single break at level, M odel B single break at a slope, and M odel C single break at both slope and level (A diguzel, 2014: 46).

Hypotheses for the ARDL model were formed as follows:

$H_{0}: \varepsilon_{1}=\varepsilon_{2}=\cdots=\varepsilon_{3}=0 \rightarrow$ There is cointegration.
$H_{0}: \varepsilon_{1} \neq \varepsilon_{2} \neq \cdots \neq \varepsilon_{3} \neq 0 \rightarrow$ There is no cointegration.

Hypothesis tests are tested by comparing the $F$ test table values and calculated values. If the value $\mathrm{F}$ is higher than the upper critical value of the table, there is cointegration between the series and the established $\mathrm{HO}$ hypothesis is accepted. In addition, the ARDL long-term coefficients are estimated. The ARDL model created within the framework of the analysis is as follows.

$\Delta$ gini $=\alpha_{0}+\sum_{i=1}^{m} \alpha_{1 i} \Delta \operatorname{gini}_{t-1}+\sum_{i=0}^{n} \alpha_{2 i} \Delta e g_{t-i}+\sum_{i=0}^{p} \alpha_{3 i} \Delta e g_{t-i}^{2}+\sum_{i=0}^{r} \alpha_{4 i} \Delta d u m m y_{t-i}+\varepsilon_{i}$

After determining the long-term coefficients of the ARDL model, if there are no problems in diagnostic tests in the model, the error correction model is estimated. The error correction model established within the scope of the analysis is as follows.

$$
\begin{aligned}
\Delta \text { gini }=\alpha_{0}+ & \sum_{i=1}^{m} \lambda_{1 i} \Delta \text { gini }_{t-1}+\sum_{i=0}^{n} \lambda_{2 i} \Delta e g_{t-i}+\sum_{i=0}^{p} \lambda_{3 i} \Delta e g_{t-i}^{2}+\sum_{i=0}^{r} \lambda_{4 i} \Delta \text { dummy }_{t-i} \\
& +\lambda_{5} \text { ECM }_{t-1}+\varepsilon_{i}
\end{aligned}
$$

The variable added to the model as EC is the error correction term. This term states to the lagged value of the residuals of the model in which the long-term relationship between variables is obtained. And the coefficient of the term ECM reveals how much of an imbalance that occurs in the short-term will improve in the long-term. The error correction term must be negative and significant.

\section{RESULTS}

Within the scope of the analysis, the unit root degrees of the series must be defined first. Because unit root research plays a decisive role in determining the model that should be used. In this context, the K PSS unit root test and the Ziwot A ndrews unit root test, which considers account structural breaks, were applied to the series. The results from the relevant tests are shown in Tables 1 and 2. 
Table 1. KPSS Unit Root Test Results

\begin{tabular}{|l|c|c|c|c|}
\hline \multirow{2}{*}{ Variables } & \multicolumn{2}{|c|}{ KPSS } & \multicolumn{2}{c|}{ KPSS (-1) } \\
\cline { 2 - 5 } & Constant & $\begin{array}{c}\text { Constant- } \\
\text { Trending }\end{array}$ & Constant & $\begin{array}{c}\text { Constant- } \\
\text { Trending }\end{array}$ \\
\hline EconomicG rowth (EG) & $0.105294^{*}$ & $0.066960 *$ & $0.094217^{*}$ & $0.093474 *$ \\
\hline EconomicG rowth (EG ${ }^{2}$ ) & $0.131682^{*}$ & $0.126478^{*}$ & $0.252612^{*}$ & $0.252750^{*}$ \\
\hline GINI Coefficient (GINI) & 0.569564 & 0.139218 & $0.255268^{*}$ & $0.161681^{*}$ \\
\hline \multicolumn{5}{|c|}{ KPSS Table Critical Values } \\
\hline$\% 1$ & 0.739000 & 0.216000 & 0.739000 & 0.216000 \\
$\% 5$ & 0.46300 & 0.146000 & 0.463000 & 0.146000 \\
$\% 10$ & 0.347000 & 0.119000 & 0.347000 & 0.119000 \\
\hline
\end{tabular}

$*: 0.01 ; * *: 0.05$ indicates the level of significance.

A ccording to the K PSS unit root test results, the Gini coefficient variable contains unit root at the level value. The economic growth variable does not contain unit root in the level value. B ased on the results, the difference process was implemented to the series and it was specified that all series did not contain unit root at the first difference level.

Table 2. Ziwot Andrews Unit Root Test Results

\begin{tabular}{|l|c|c|c|c|}
\hline Variables & Model A & Break & Model C & Break \\
\hline GINI Coefficient (GINI) & -4.645928 & & -2.900844 & \\
& $(0.012183)$ & 2006 & $(0.008337)$ & 2006 \\
\hline \multirow{2}{*}{ Economic Growth (EG) } & -6.637613 & & -6.463297 & \\
\hline \multirow{2}{*}{ Economic Growth $\left(\mathrm{EG}^{2}\right)$} & $(0.080509)$ & 2003 & $(0.071818)$ & 2003 \\
\hline
\end{tabular}

A ccording to Ziwot A ndrews unit root test results, which take structural breaks into account, M odel A shows the model a constant and M odel $C$ shows a constant-trending. The results for the Gini coefficient do not contain unit roots in the context of Model $A$ and M odel $C$. The breaking date was found as 2006.T he economic growth variable does not contain unit root in M odel $\mathrm{A}$ and M odel $\mathrm{C}$ and the breaking date was determined as 2003.

When the unit root tests applied to the series were evaluated, it was understood that the series were stationary at different level values and it was decided that the ARDL model was suitable for investigating the cointegration relationship between the series. As a first step, the lag lengths of the variables in the model were determined. For this purpose, The $(4,2,3,0)$ model was selected among 20 alternative models within the framework of the AIC (Akaike Information Criteria). 
Figure 2. Alternative Models for Lag Length

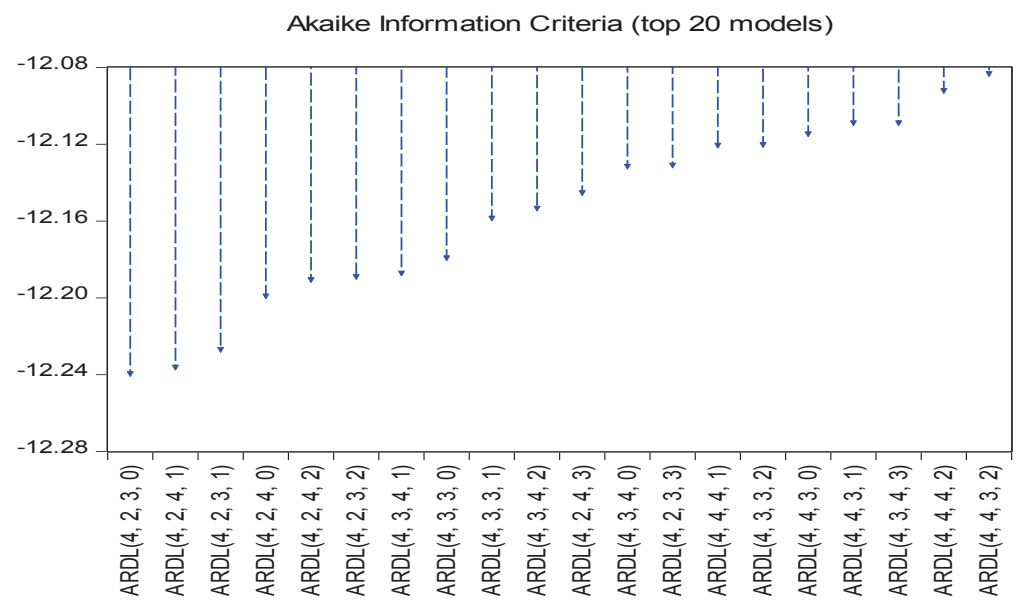

Model estimates were evaluated and lag lengths in the model were determined as $(4,2,3,0)$. The first step for the prediction results of the relevant model is the ARDL bounds test. B ounds testingfindings are revealed in Table 3.

\section{Tablo 3. Bounds Testing Results}

\begin{tabular}{|l|c|c|}
\hline BoundsTestingResults & I(0) & I(1) \\
\hline Table Critical Values & 2.97 & 3.94 \\
\hline$\% 10$ & 3.38 & 4.23 \\
\hline$\% 5$ & 4.3 & 5.23 \\
\hline$\% 1$ & 24.65280 \\
\hline Calculated F Statistic Value & $2.203457(0.1499)$ \\
\hline \multicolumn{2}{|c|}{ DiagnosticTests } \\
\hline Breush-GodfreySerialCorrelation LM Test & $9.467714(0.08792)$ \\
\hline Jaque Bera Normality Test & $0.737989(0.7057)$ \\
\hline $\begin{array}{l}\text { ARCH Statistical Value of Heteroskedasticity } \\
\text { Test }\end{array}$ & $0.042582(0.9666)$ \\
\hline RamseyReset &
\end{tabular}

In the model, the calculated F statistic value was found as 24.65280 . In order to determine the significance of the bounds testing, the calculated F statistic value was compared with the table critical values. The results show that the calculated $F$ statistic value is greater than the table upper values at all probability levels. From this point, the $\mathrm{H}_{1}$ hypothesis was accepted and the existence of a cointegration relationship between variables was determined. W ith this result, it was concluded that the variables in the analysis were cointegrated in the long-term.

When the diagnostic test results of the model are evaluated, it is revealed that the model does not have auto-correlation, varying variance, and normal distribution problems. The results 
enable the estimation of long-term coefficients and the establishment of error correction model. The estimated long-term coefficients are given in table 4.

Table 4. Estimated Long-Run Coefficients

\begin{tabular}{|l|c|c|c|}
\hline Variables & Coefficient & tStatistic Value & Probability Value \\
\hline EconomicG rowth (EG) & -0.001473 & -4.796686 & $0.0002^{*}$ \\
\hline EconomicGrowth $\left(\mathrm{EG}^{2}\right)$ & 0.002570 & 3.477286 & $0.0034^{*}$ \\
\hline Dummy & -0.0101108 & -5.203466 & $0.0001^{*}$ \\
\hline
\end{tabular}

*: 0.01 indicates the level of significance.

The long-term coefficients of the variables state that the relationship between economic growth and the Gini coefficient, which indicates income inequality, is statistically significant. When the signs of these coefficients are evaluated, it is seen that the sign of the economic growth variable is negative (-) and the sign of the square of economic growth is positive (+). This indicates that K uznets' inverted-U hypothesis isn't valid in Turkey during the relevant period and that the relationship between variables is $U$-shaped because income inequality decreases as economic growth increases.

Error correction model results showing the state of elimination of short-term imbalances over the long-term are in Table 5.

Table 5. Results of Error Correction Model

\begin{tabular}{|c|c|c|c|c|}
\hline Variable & Coefficient & Std. Error & t-Statistic & Prob. \\
\hline $\mathrm{D}(\mathrm{GINI}(-1))$ & 0.062655 & 0.068991 & 0.908171 & 0.3781 \\
\hline $\mathrm{D}(\mathrm{GINI}(-2))$ & 0.584151 & 0.068329 & 8.549144 & 0.0000 \\
\hline $\mathrm{D}(\mathrm{GINI}(-3))$ & 0.313352 & 0.066530 & 4.709942 & 0.0003 \\
\hline $\mathrm{D}(\mathrm{EG})$ & $-8.96 \mathrm{E}-05$ & $1.86 \mathrm{E}-05$ & -4.817017 & 0.0002 \\
\hline $\mathrm{D}(\mathrm{EG}(-1))$ & 0.000154 & $1.64 \mathrm{E}-05$ & 9.343861 & 0.0000 \\
\hline $\mathrm{D}\left(\mathrm{EG}^{2}\right)$ & $2.32 \mathrm{E}-05$ & $3.60 \mathrm{E}-06$ & 6.442844 & 0.0000 \\
\hline $\mathrm{D}\left(\mathrm{EG}^{2}(-1)\right)$ & $-4.36 \mathrm{E}-05$ & $4.63 \mathrm{E}-06$ & -9.429432 & 0.0000 \\
\hline $\mathrm{D}\left(\mathrm{EG}^{2}(-2)\right)$ & $-3.05 \mathrm{E}-05$ & $3.33 \mathrm{E}-06$ & -9.166090 & 0.0000 \\
\hline CointE q(-1)* & -0.226074 & 0.018093 & -12.49538 & 0.0000 \\
\hline
\end{tabular}

The estimated error correction coefficient has a negative sign and is statistically significant. These findings show that the short-term imbalances in the model are removed in the long term. It shows that approximately $20 \%$ of the difference between the observed value of the Gini coefficient and the equilibrium value disappears in one year and all of it disappears within 5 years.

The fact that the prediction of consecutive errors in the CUSUM test is the same in the long term and remains the same for a long time indicates uncertainty. This situation expresses uncertainty. CUSUM test results are shown in Figure 2. 


\section{Figure 3. CUSUM Test Results}
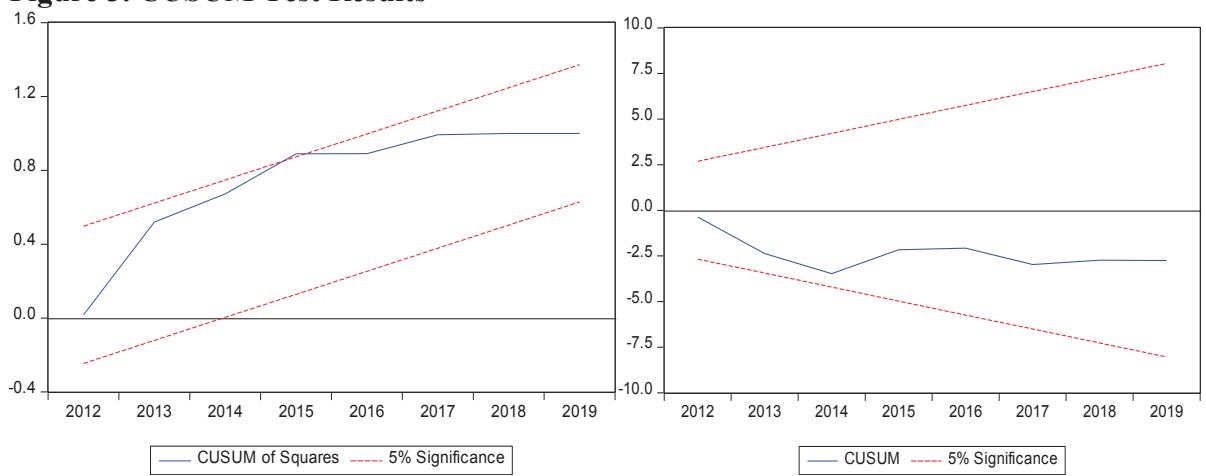

The fact that the CUSUM test graph does not deviate from the $5 \%$ range and its values are changed over time indicates that there is no structural break in the model. CUSUM sq test chart is calculated with consecutive error squares and expresses whether there is a structural break in the specified confidence interval. The CUSUM sq in the right panel of Figure 3 shows that there is no structural break at the specified confidence interval.

\section{DISCUSSION}

The primary aim of all production processes of countries is to provide economic growth. Its aim after economic growth is to ensure a fair distribution of income created by economic growth between individuals or factors of production (labor, capital, natural resources and entrepreneur). A fair distribution of income, which is carried out in a way that is co-driven with economic growth, is very important in terms of achieving socio-economic balance. Because of this importance, the relationship between income distribution and economic growth has been studied for a long time. In order to contribute to these studies, the relationship between income distribution inequality and economic growth in Turkey was analyzed on the basis of Kuznets' inverted-U hypothesis. According to the results of the analysis, the established quadric model showed a negative relationship between economic growth and income inequality, and a positive relationship between income inequality and the square of economic growth. This indicates that economic growth initially reduces income inequality in the relevant period in Turkey, and in later stages of economic growth increases income inequality after a threshold value. It is seen that the obtained results are similar to the studies of Disbudak and Suslu (2009), K anberogluand A rvas (2014), A Itunoz (2015), Dogan and Cafri (2016), Altıntas and Ak (2016), and Tosun and Cakmak (2017) in the literature.

\section{CONCLUSION}

The primary aim of all production processes of countries is to ensure economic growth. Its aim after economic growth is to ensure a fair distribution of income created by economic growth between individuals or factors of production (labor, capital, natural resources, and entrepreneur). Equitable distribution of income, which is carried out simultaneously with economic growth, is very important in terms of achieving socioeconomic balance. B ecause of this importance, the relationship between income distribution and economic growth has been 
investigated for a long time. Although the relationship between variables has been investigated for a long time, the history of empirical studies conducted to determine the direction and degree of the relationship does not date back too far. The main reason for this is that the data that will be used to measure income distribution, in particular, cannot be obtained completely.

The most accepted hypothesis in determining the relationship between income inequality and economic growth is the inverted- $U$ hypothesis put forward by Kuznets (1955). This hypothesis argues that there will be a positive relationship between economic growth and income inequality in the early stages of a society's economic development, and a negative relationship between income inequality and economic growth in the later stages of its economic development. In this context, the relationship between economic growth and income inequality in the Turkey economy was analyzed on the basis of K uznets ' inverted-U hypothesis.

According to the results of the analysis, the established quadric model showed a negative relationship between economic growth and income inequality (Gini coefficient) and a positive relationship between income distribution inequality and the square of economic growth. This situation implies that in the early stages of economic development, income inequality decrease with economic growth, and in the later stages of economic growth, income inequality increase with economic growth in the relevant period in Turkey.

Production of technology-intensive and value-added products to sustain economic growth performance in the coming period is necessary for Turkey. With the support of these processes, the demand for qualified workforce will increase and this will reflect positively on income distribution in the long run. Structural reforms that will ensure the participation of working conditions in the labor market, increase productivity, increase registration, encourage quality development and vocational training are very important to transform production, the labor market and income distribution. In addition to these, taking care of the disadvantaged groups and those under the risk of social exclusion and facilitating their access to opportunities, extending social assistance and social services, and increasing the quality of life will make significant contributions to reducing poverty and injustice in income distribution.

\section{TÜRKIYY'DE KUZNETS'İN TERS-U HIPOTEZİ GEÇERLİ Mİ?: ARDL SINIR TESTI YAKLAŞIMI}

\section{GİRIŞ}

Ekonomi politikalarının en önemli amaçları arasında istikrarlı ve sürdürülebilir ekonomik büyüme yanında yaratılan gelirin adaletli bir şekilde dağılımını sağlamak yer almaktadır. Bu amaçlara ulaşmak için dünya da farklı ekonomi politikaları uygulanmaktadır. Uygulanan politikaların ekonomik büyümede belirli dönemlerde ilerlemelere neden olmasına karşın gelir eşitsizliğinde yetersiz kaldığı hatta son yıllarda (1990’ların sonları ve 2000'li yılların başları) gelir eşitsizliğinin yüksek, orta ve düşük gelirli ülkelerin genelinde artış gösterdiği görülmektedir (UNDP, 2013: 63-67). 
Son yıllarda dünyanın birçok ülkesinde yüksek büyüme oranlarına ulaşılmasına rağmen ekonomik büyümede yaşanan bu olumlu seyrin gelir eşitsizliğine aynı düzeyde yansımaması hatta çoğunlukla olumsuz bir şekilde yansıyarak gelir eşitsizliğini artırması araştırmacıların ilgisini çekmiştir. Bunun üzerine Kuznets (1955) bu noktadan hareketle ekonomik büyüme ile adaletsiz gelir dağılımı arasında ilişki var mı? Varsa nasıl bir ilişki vardır? Sorularının cevaplarını araştırmaya başlamış ve araştırmasının sonunda ekonomik büyüme ile gelir dağılımı eşitsizliği arasındaki ilişkinin "ters U” şekline benzediğini ortaya koymuş ve buna da "ters-U hipotezi” adını vermiştir. Kuznets (1955) tarafından ortaya atılan bu hipotez ilk zamanlar çok fazla tartışılsa da son yıllarda yapılan ampirik çalışmalar ekonomik büyüme ile gelir eşitsizliği arasındaki ilişkinin her ülke ya da ülke grubunda farklı şekilde ortaya çıktığını göstermektedir. Bu noktadan hareketle bu çalışmanın amacı Kuznets (1955)'in ortaya atmış olduğu ters-U hipotezinin Türkiye ekonomisinde 1987-2019 döneminde geçerli olup/olmadığını analiz etmektir.

\section{YÖNTEM}

Kuznets'in ters-U hipotezinin Türkiye'de geçerli olup/olmadığını test etmek amaciyla kurulan modelde bağımlı değişken olarak gelir dağılımı eşitsizliğini temsil etmesi açısından Gini katsayısı bağımsız değişken olarak ise ekonomik büyümeyi temsil etmesi açısından kişi başına gayri safi yurtiçi hasıla büyümesi (\%) kullanılmıştır. 1987-2019 dönemine ait Gini Katsayısı verisi Solt (2016) tarafından oluşturulan Standardize Edilmiş Dünya Gelir Dağılımı Eşitsizliği Veri Tabanı (SWIID-Versiyon 9.0)'ndan ve ekonomik büyümeyi temsil etmesi açısından kişi başına gayri safi yurtiçi hasıla büyümesi (\%) Dünya Bankası'nın Dünya Gelişme Göstergeleri veri tabanından temin edilmiştir.

Çalışmada diğer eşbütünleşme testlerine göre önemli avantajlara sahip olan ARDL sınır testi yaklaşımı kullanılmış olup, ilk olarak serilerin birim kök içerip içermediklerini tespit etmek amacıyla serilere KPSS ve Ziwot Andrews birim kök testi uygulanmış ve ARDL modeli için ilk aşama olarak modeldeki değişkenlerin gecikme uzunlukları tespit edilmiştir. Uygun gecikme uzunluğuna göre sınır testi ve sonrasında uzun dönem katsayı tahmini ve hata düzeltme modeli uygulanmıştır.

\section{BULGULAR}

Çalışmada KPSS birim kök testi sonuçlarına göre, Gini katsayısı değişkeninin düzey değerinde birim kök içerdiği, ekonomik büyüme değişkeninin ise düzey değerinde birim kök içermediği tespit edilmiştir. Elde edilen sonuçlara istinaden serilere fark alma işlemi uygulanmış ve tüm serilerin birinci fark düzeyinde birim kök içermedikleri sonucuna ulaşılmıştır. Yapısal kırılmaları dikkate alan Ziwot Andrews birim kök test sonuçlarına göre, Gini katsayısı için elde edilen sonuçlar sabitli Model A ve sabitli-trendli Model C bağlamında birim kök içermediği ve bu değişken için kırılma tarihi 2006 yılı olarak tespit edilmiştir. Ekonomik büyüme değişkeni için ise sabitli Model A ve sabitli-trendli Model C bağlamında birim kök içermediği ve kırılma yılının 2003 olduğu sonucuna varılmıştır. Serilerin farklı düzeylerde durağan olduğu tespit edildikten sonra ARDL sınır testi yaklaşımı için ilk aşama olarak gecikme uzunlukları $(4,2,3,0)$ olarak belirlenmiş, sonrasında sınır testi ve uzun dönem 
katsayı tahminine göre ekonomik büyüme ile gelir eşitsizliği arasında negatif yönlü bir ilişkinin varolduğu tespit edilmiştir.

\section{TARTIŞMA}

Araştırmanın bulgularına göre, Türkiye'de ekonomik büyüme ile gelir dağılımı eşitsizliği arasında negatif bir ilişki bulunurken, gelir dağılımı eşitsizliği ile ekonomik büyümenin karesi arasında pozitif bir ilişkiye ulaşılmıştır. Türkiye ekonomisinde, gelir eşitsizliğinin azaltılmasında ekonomik büyümenin gerekliliğinden yola çıkıldığında büyümenin sürdürülebilirliği öncelik arzetmektedir. Bu doğrultuda teknoloji yoğun katma değeri yüksek ürünlere ait üretim süreçlerinin desteklenmesi gerekmektedir. Türkiye'de üretim, işgücü piyasası ve gelir dağılımında bu sürecin gerçekleşebilmesi için öncelikli olarak; çalışma koşullarının işgücü piyasalarına katılımını sağlayacak, verimlilik artışını gerçekleştirecek, kayıtlılı̆̆ 1 artıracak, nitelik geliştirmeyi ve mesleki eğitimi özendirecek yapısal reformların hayata geçirilmesi son derece önemlidir. Bunların yanında dezavantajlı kesimlerin ve sosyal dışlanma riski altında bulunanların gözetilmesi ve firsatlara erişiminin kolaylaştııılması, sosyal yardım ve sosyal hizmetlerin yaygınlaştırılması ve yaşam kalitesinin yükseltilmesi yoksulluğun ve gelir dağılımındaki adaletsizliğin azaltılmasında önemli katkılar sağlayacaktır.

\section{SONUÇ}

Ülkelerin tüm üretim süreçlerinin öncelikli amacı ekonomik büyümeyi sağlamaktır. Ekonomik büyümeden sonraki amacı ise ekonomik büyüme sayesinde yaratılan gelirin bireyler ya da üretim faktörleri (emek, sermaye, doğal kaynak ve girişimci) arasında adil dağılımını temin etmektir. Ekonomik büyüme ile eş güdümlü bir şekilde gerçekleştirilen adaletli gelir dağılımı sosyo-ekonomik dengenin sağlanması açısından oldukça önemlidir. Bu öneminden dolayı gelir dağılımı ve ekonomik büyüme arasındaki ilişki uzun zamandan beri araştırılmaktadır. $\mathrm{Bu}$ araştırmalara katkı sağlamak amacıyla çalışmada Türkiye'de gelir dağılımı eşitsizliği ve ekonomik büyüme ilişsisi Kuznets'in ters-U hipotezi temelinde analiz edilmiştir. Analiz sonuçlarına göre, kurulan kuadrik model ekonomik büyümeyi ile gelir dağılımı eşitsizliği arasında negatif bir ilişki devamında gelir dağılımı eşitsizliği ile ekonomik büyümenin karesi arasında pozitif bir ilişki olduğunu göstermiştir. Bu durum Türkiye'de ilgili dönemde başlangıç olarak ekonomik büyümenin gelir dağılımında eşitsizliği azalttığını, ekonomik büyümenin ilerleyen safhalarında ise bir eşik değerden sonra gelir dağılımındaki eşitsizliği artırdığını ifade etmektedir. Türkiye ekonomisinde, ilerleyen dönemde ekonomik büyüme trendinin sürdürülebilir olabilmesi için öncelikli olarak teknoloji yoğun katma değeri yüksek ürünlere ait üretim süreçlerinin desteklenmesi gerekmektedir. Bu süreçlerin desteklenmesi ile birlikte nitelikli işgücüne olan talep artacak ve bu durumda uzun dönemde gelir dağılımına olumlu yönde yansıyacaktır. 


\section{REFERENCES}

A cemoglu, D. \& Robinson, J. A. (2002). The political economy of the K uznets curve. Review Of Development Economics, 6(2), 183-203.

Adıgüzel, U. (2014). "Türkiye'de Kamu Harcamaları Dış Ticaret Açıkları Üzerinde Etkili mi?". Akademik Araştırmalar ve Çalışmalar Dergisi, 6(10), 39-55.

Ak, M. Z. \& Altıntaş, N. (2016). "Kuznets'in Ters U Eğrisi Bağlamında Türkiye'de Gelir Eşitsizliği ve Ekonomik Büyüme İlişkisi: 1986-2012”. Maliye Araştırmaları Dergisi, Cilt:2, Say1:3, 93-102.

A kalin, G.; Özbek, R. İ. \& Çifci, İ. (2018). “Türkiye'de Gelir Dağılımı ve Ekonomik Büyüme Arasındaki İlişki: ARDL Sınır Testi Yaklaşımı”. Kastamonu Üniversitesi İktisadi ve İdari Bilimler Fakültesi Dergisi, 2018, 20 (4), 59-76.

Akel, V. \& Gazel, S. (2014). "Döviz Kurları ile BİST Sanayi Endeksi Arasındaki Eşbütünleşme İlişki: Bir ARDL Sınır Testi Yaklaşımı”. Erciyes Üniversitesi İktisadi ve İdari Bilimler Fakültesi Dergisi, 0(44), 23-41.

Akyol, H. (2020). "Turizm Faaliyetleri ve Ekonomik Büyüme ile Gelir Eşitsizliği Arasındaki İlişkinin İncelenmesi: Gelişmiş ve Gelişmekte Olan Ülkeler Örneği”. Journal of Humanities and Tourism Research, 10 (4): 966-977.

Altunöz, U. (2015). "Kuznet Eğrisi Bağlamında Türkiye'de Finansal Gelişme v e Gelir Eşitsizliği İlişkisinin Analizi”, Editors: Selahattin Sarı, Alp H. Gencer ve İlyas Sözen, International Conference On EurasianEconomies, K azan-Russia 871-875.

Bahmani-Oskooee, M. \& G elan, A. (2008). "Kuznets inverted-U hypothesis revisited: a timeseries approach using US data". Applied Economics Letters, 15(9), 677-681.

Cowell, F. A. (2007). Income Distribution and Inequality. Suntory and Toyota International Centres for Economics and Related Disciplines (STICERD), Distributional A nalysis Research Programme Discussion Paper, London.

Çakma, A. İ. \& Tosun, B. (2017) "Ekonomik Büyüme-Gelir Dağılımı İlişkisi: Kuznets Hipotezinin Seçilmiş Ülkeler Üzerine Araştırılması”, Kocaeli Üniversitesi Sosyal Bilimler Dergisi, K OSB ED, 33, 33-44.

Çelik, T. T. \& Taş, O. (2007). Etkin Piyasa Hipotezi ve Gelişmekte Olan Hisse Senedi Piyasalar1, İÜ̈ Dergisi, 4(2), 11-22.

Deutsch, J., \& Silber, J. (2004). M easuring the impact of various income sources on the link between inequality and development: Implications for the Kuznets curve. Review of Development Economics, 8(1), 110-127.

Dişbudak, C. \& Süslü, B. (2009). "Kalkınma ve Bireysel Gelir Dağılımı: Kuznets Hipotezi Türkiye için Geçerli mi?”. Akdeniz Üniversitesi İktisadi ve İdari Bilimler Fakültesi Dergisi, 9(18), 146- 166.

Doğan, N. \& Cafrı, R. (2016). "W hich Hypothesis Is V alid in OECD Countries, K uznets U Curve Or Great U-Turn? System GM M Estimation for Dynamic Panel Data”. Ç.Ü. Sosyal Bilimler Enstitüsü Dergisi, Cilt 25, Sayı 3, 411-426.

Engle, R. F. \& Granger. C. W. J. (1987). "Cointegration and Error Correction: Representation, Estimation and Testing”, Econometrica, 55 (2), 225-253.

Günel, T. (2020). “Türk Cumhuriyetleri'nde Kuznets Ters U Hipotezi Testi, Finans Politik \& Ekonomik Yorumlar, (651), 99-112.

Ivic, M. M. (2015). "Economic Growth and Development". (JPMNT) Journal of Process Management - New Technologies, International V ol. 3, N 0.1, 55-62. 
Johansen, S. (1988), "Statistical Analysis of Cointegration Vectors", Journal of Economics Dynamic and Control, 12(2-3), 231-254.

Kanberoğlu, Z. \& A rvas, M. A. (2014). "Finansal Kalkınma ve Gelir Eşitsizliği: Türkiye Örneği, 1980-2012, Sosyoekonomi, 2014-1, 105-122.

Kuznets, S. (1955). Economic growth and income inequality. The American economic review, 45(1), 1-28.

K uznets, S. (1963). Quantitative aspects of the economic growth of nations: V III. Distribution of income by size. Economic development and cultural change, 11(2, Part 2), 1-80.

K waitkowski, D.; Phillips, P.; Schmidt, P. \& Shin, Y . (1992). "Testing The Null Hypothesis Of Stationarity A gainst The Alternative Of A Unit Root: How Sure Are We That Economic Time Series Have A Unit Root?", Journal Of Econometrics, 54: 159-178.

Limanl1, Ö. (2020). Kuznets'in Ters-U Hipotezi: Türkiye Özelinde K1sa Bir Tartışma”. İktisadi İdari ve Siyasal Araştırmalar Dergisi (IKKTiSAD), 5(12), 156-167.

List, John A.\& Gallet, Craig A. (1999). "The Kuznets Curve: W hat Happens A fter the Inverted-U?". Review of Development Economics, 3(2), 200-206.

Lyubimov, I. (2017). Income inequality revisited 60 years later: Piketty vs K uznets. Russian Journal of Economics, 3(1), 42-53.

M ercan, M . \& Azer, O.A. (2013). "The Relationship between Economic Growth and Income Distribution in Turkey and the Turkish Republics of Central A sia and Caucasia: Dynamic Panel Data Analysis with Structural Breaks". Eurasian Econ Rev, 3, 165182.

Perron, P. (1997). "Further Evidence on Breaking Trend Functions in Macroeconomic Variables", Journal of Econometrics, vol. 80, no. 2, 355-385.

Pesaran, M. H.; Shin, Y . \& Smith R. (2001). "Bounds Testing Approaches to the Analysis of Level Relationships", Journal of Applied Econometrics, 16, 289-326.

Ram, R. (1989), "Level of Development and Income Inequality: An Extension of KuznetsHypothesis to the W orld Economy". Kyklos, 42(1), 73-88.

Shahbaz, M. (2010), "Income Inequality-Economic Growth And Non-Linearity: A Case of Pakistan”. International Journal of Social Economics, 37(8), 613-636.

Solt, F. (2016). "The Standardized World Income Inequality Database." Social Science Quarterly. 97 (5): 1267-1281.

Solt, F. (2019), "The Standardized World Income Inequality Database, Versions 89", Harvard Dataverse, V 5, https://dataverse.harvard.edu/dataset.xhtml?persistentld =doi:10.7910/DV N/L M 40W F

Solt, F. (2020). "M easuring Income Inequality Across Countries and Over Time: The Standardized W orld Income Inequality Database." Social Science Quarterly, 101 (3): 1183-1199.

Takım, A.; Ersungur, Ş. M.; Tural Dikmen, A.\& A ksu, L. E. (2020). "Türkiye'de Ekonomik Büyüme ile Gelir Dağılımı Arasındaki İlişki”, Atatürk Üniversitesi İktisadi ve İdari Bilimler Dergisi, Ocak 2020, 34(1), 227-240.

Tokatlığlu, I., \& A tan, M. (2007), "Türkiye'de Bölgeler Arası Gelişmişlik Düzeyi ve Gelir Dağılımı Eşitsizliği: Kuznets Eğrisi Geçerli Mi?”, Ekonomik Yaklaşım, 18(65), 25- 58.

Topuz Şahin, S. (2016). "Ekonomik Büyüme ve Gelir Eşitsizliği İlişkisi: Kuznets Ters-U Hipotezi’nin Geçerliliği”, Eskişehir Osmangazi Üniversitesi İ̈BF Dergisi, 11(3), 115130. 
United Nations Development Programme (UNDP) (2013). Humanity Divided: Confronting Inequality in Developing Countries. United Nations Development Programme Bureau for Development Policy, N ew Y ork, USA.

W eil, D. (2016). EconomicG rowth. International Edition: Routledge.

World Bank (WB). "Data Bank: World Development Indicators", http://databank.world bank.org/data/reports.aspx? source=world-development-indicators, (02.01.2021).

Y avuz Çil, N. (2004). "Durağanlığın Belirlenmesinde KPSS ve ADF Testleri: IMKB Ulusal100 Endeksi ile Bir Uygulama”. İstanbul Üniversitesi İktisat Fakültesi Mecmuası, 54(1), 239-247.

Zivot, E. \& Andrews D. (1992). "Further Evidence On The Great Grash, The Oil-Price Shock, A nd The Unit-Root Hypothesis", Journal Of Business And Economic Statistics, V ol. 10(3), 251-270.

\begin{tabular}{|c|c|c|}
\hline $\begin{array}{c}\text { KATKI ORANI / } \\
\text { CONTRIBUTION RATE }\end{array}$ & $\begin{array}{c}\text { AÇIKLAMA / } \\
\text { EXPLANATION }\end{array}$ & $\begin{array}{l}\text { KATKIDA BULUNANLAR } \\
\text { / CONTRIBUTORS }\end{array}$ \\
\hline $\begin{array}{c}\text { Fikir veya Kavram / Idea } \\
\text { or Notion }\end{array}$ & $\begin{array}{l}\text { Araştırma hipotezini veya } \\
\text { fikrini oluşturmak / Form } \\
\text { the research hypothesis or } \\
\text { idea }\end{array}$ & $\begin{array}{l}\text { Cüneyt K IL IÇ } \\
\text { Ünzüle K URT } \\
\text { Gülistan CAN }\end{array}$ \\
\hline Tasarım / Design & $\begin{array}{l}\text { Yöntemi, ölçeği ve deseni } \\
\text { tasarlamak / Designing } \\
\text { method, scale and pattern }\end{array}$ & $\begin{array}{l}\text { Cüneyt K IL IÇ } \\
\text { Ünzüle K URT } \\
\text { Gülistan CAN }\end{array}$ \\
\hline $\begin{array}{c}\text { Veri Toplama ve İşleme / } \\
\text { Data Collecting and } \\
\text { Processing }\end{array}$ & $\begin{array}{c}\text { V erileri toplamak, } \\
\text { düzenlenmek ve raporlamak } \\
\text { / Collecting, organizing and } \\
\text { reporting data }\end{array}$ & $\begin{array}{l}\text { Cüneyt K IL IÇ } \\
\text { Ünzüle K URT } \\
\text { Gülistan CAN }\end{array}$ \\
\hline $\begin{array}{l}\text { Tartışma ve Yorum / } \\
\text { Discussion and } \\
\text { Interpretation }\end{array}$ & $\begin{array}{l}\text { Bulguların } \\
\text { değerlendirilmesinde ve } \\
\text { sonuçlandırılmasında } \\
\text { sorumluluk almak / Taking } \\
\text { responsibility in evaluating } \\
\text { and finalizing the findings }\end{array}$ & $\begin{array}{l}\text { Cüneyt K IL IÇ } \\
\text { Ünzüle K URT } \\
\text { Gülistan CAN }\end{array}$ \\
\hline $\begin{array}{l}\text { Literatür Taramas1 / } \\
\text { Literature Review }\end{array}$ & $\begin{array}{c}\text { Çalışma için gerekli } \\
\text { literatürü taramak / Review } \\
\text { the literature required for } \\
\text { the study }\end{array}$ & $\begin{array}{l}\text { Cüneyt KIL IÇ } \\
\text { Ünzüle K URT } \\
\text { Gülistan CAN }\end{array}$ \\
\hline
\end{tabular}

